\title{
Variation of purchasing's involvement: case studies of supplier collaborations in new product development
}

Lisa Melander and Nicolette Lakemond

\author{
Linköping University Post Print
}

Tweet

N.B.: When citing this work, cite the original article.

Original Publication:

Lisa Melander and Nicolette Lakemond, Variation of purchasing's involvement: case studies of supplier collaborations in new product development, 2014, International Journal of procurement management, (7), 1, 103-118.

http://dx.doi.org/10.1504/IJPM.2014.057877

Copyright: Inderscience

http://www.inderscience.com/

Postprint available at: Linköping University Electronic Press

http://urn.kb.se/resolve?urn=urn:nbn:se:liu:diva-103935 


\title{
Variation of purchasing's involvement: case studies of supplier collaborations in new product development
}

\author{
Lisa Melander ${ }^{1}$ and Nicolette Lakemond \\ ${ }^{1}$ Department of Management and Engineering, Linköping University, Sweden, \\ lisa.melander@liu.se, nicolette.lakemond@liu.se
}

\begin{abstract}
Firms are increasingly involving suppliers in new product development (NPD) and one reason for this is to access technological knowledge. Previous research argues that purchasing fulfils an important role in involving the suppliers in NPD. However, purchasing's role under technological uncertainty has not been investigated in detail. The purpose of this paper is to explore purchasing's role in technology selection, supplier selection and level of participation in NPD projects involving suppliers. Three NPD projects at one large high-tech firm are studied. The results show that purchasing has limited influence in the technology selection process, but fulfils an important role in the selection of the supplier and has a role as a trouble-shooter throughout the collaborative NPD projects. Purchasing does not necessarily need to be involved in solving daily, routine problems, but serves as a trouble-shooter to solve problems related to the supplier's strategy, the relationship with the supplier, and commitment issues.
\end{abstract}

Keywords: Purchasing; New Product Development; Supplier Management; Technology Selection; Supplier Selection; Case Studies 


\section{Introduction}

The importance of the purchasing function as an important function contributing to a firm's long-term performance is receiving increasing attention (Carr and Pearson 2002; Chen et al. 2004; Paulraj et al. 2006). In many firms, purchasing has evolved into a strategic function and is considered by top management to be an important resource. In these firms, the purchasing staff contributes with their own expertise and by involving key suppliers in the firm's planning process (Carr and Pearson 2002). The importance of purchasing encompasses new product development activities (NPD), especially when suppliers actively participate in these activities. It has been proposed that purchasing plays an important role in managing the suppliers and supporting the R\&D function (Wynstra, Weggeman and van Weele, 2003). More precisely, purchasing does not necessarily contribute only with cost, quality and deliverability issues (Dowlatshahi 1998), but also by linking innovation and sourcing strategies through technology road mapping with suppliers. This can form an important basis for supplier selection (Schiele 2010). Consequently, it can be argued that purchasing fulfils an essential role in achieving the potential benefits of supplier involvement in NPD. The role played by purchasing in technology selection, supplier selection, and participation in NPD is considered to be a best practice (Schiele 2010).

Whether or not the benefits of supplier involvement in NPD also apply for technologically uncertain NPD projects is still widely debated (Johnsen 2009). In some studies positive effects have been observed (Petersen et al. 2003; Song and Di Benedetto 2008), while in other studies no benefits from involving suppliers in technological uncertain NPD projects were found (Eisenhardt and Tabrizi 1995; Primo and Amundson 2002). It has been speculated that unpredictable technology makes it difficult to identify suitable suppliers up-front, and consequently, in order to maintain design flexibility, suppliers may be involved only in the latest stages of product development or not at all (Eisenhardt and Tabrizi 1995). This makes sense when all technologies reside within one firm as supplier involvement mainly considers manufacturability issues. However, in many complex NPD projects, suppliers may be an important complementary source of knowledge (Enkel et al. 2009). Projects with technological uncertainty might require the integration of supplier technologies in NPD. Under these circumstances, supplier involvement may differ considerably from supplier involvement under technological certainty. Previous research points at the importance of integrating these suppliers into the NPD team (Petersen et al. 2003; Ragatz et al. 2002), and to 
selecting technical capable suppliers (Wasti and Liker 1997; Wynstra et al. 2010). Despite these valuable insights, the investigation of supplier involvement under technological uncertainty has been identified as a fruitful avenue for research as there is a lack of complementary insights such as how buyers and supplier can align their technology roadmaps (Petersen et al. 2003). Although the importance of purchasing for managing supplier involvement in NPD projects has been identified, its specific role under technological uncertainty could be further investigated.

Hence, the purpose of this paper is to explore purchasing's role in technology selection, supplier selection and level of participation in NPD projects involving suppliers. In this paper, purchasing refers to the purchasing department, which in some companies is also referred to as procurement, sourcing or the supply management function at the firm. As the paper is explorative and aims to capture the complexity of the phenomenon rather than statistical relationships, the study is based on three NPD projects within one single firm. This firm acts as a systems-integrator of complex products. All three projects were subject to a high degree of technological uncertainty. The aim of each project was to develop a completely new product, building largely on the technology provided by an external supplier. These technologies were not available in-house in the buyer's organization. Thus, the complementary knowledge the suppliers provided is related to the technology and not to the NPD process or the production.

Our findings suggest that purchasing's role in the technology selection may be limited. In the projects studied, purchasing was not involved in the technology selection for the NPD projects, which indicates that purchasing may not be most suitable for evaluating new technologies. In one of the studied projects for instance, an external expert was hired to evaluate possible technologies. Hence, the firm chose to consult externally rather than internally. However, purchasing was involved and fulfilled an important role in the supplier selection. The main finding from this study indicates that purchasing has an important role as a trouble-shooter in collaborative NPD projects. In contrast to predictions in the literature, where purchasing's well-established participation in the project team is suggested as a best practice, our studies show that purchasing's trouble-shooter role is not limited to being a member of the project team. Indeed, in two of the projects studied, purchasing was not involved continuously in the NPD team but could step in at crucial moments and help to solve major problems related to the supplier collaboration. However, one project also showed that purchasing's role as a trouble-shooter does not prevent members of this function from being 
project members. We argue that in contrast to previous roles identified in the literature (see eg Knight and Harland 2005; Oh and Rhee 2010; Wu et al. 2010) where purchasing solves problems that occur in daily operations or routine problems, purchasing working as a troubleshooter solves larger problems that are related to the supplier relationship, the supplier's strategies and commitment issues.

The paper is structured as follows. The following section outlines our theoretical framework for purchasing's role in NPD. Thereafter, section three describes the methodology and design of the empirical case studies. Section four consists of a description of the three case studies with a focus on purchasing's involvement in the NPD collaborations. In section five, an analysis of the cases is provided using the suggested framework. This also provides the conclusions, limitations of this study and suggestions for future research.

\section{Purchasing's role in NPD}

The traditional view of purchasing is that it manages inputs, ensures that these are delivered on time, are of sufficient quality, and are at an acceptable price. In addition, purchasing looks for new suppliers, assesses and selects these new suppliers, is responsible for the contact with existing suppliers and also negotiates prices. These activities can be translated into a rationalization role, i.e. contributing to the firm's competitiveness by focusing on production cost, logistics, and prices of sourced products, and a structural role which refers to managing the supplier network and making sure that suitable suppliers are available (Wynstra et al. 2003). When suppliers increasingly become involved in NPD, purchasing acquires an additional role.

Purchasing can address issues on both operational and strategic levels (Das and Narasimhan 2000; Tomino et al. 2012). Schiele (2010) refers to the dual role of purchasing, adding an innovation-orientation to the more traditional cost-orientation. This innovationorientation also concerns aligning internal development activities with development activities at suppliers, and includes ensuring that the supplier's technical competencies are exploited and committing the suppliers' activities to the NPD project (Wynstra et al. 2003). It seems that firms that view purchasing as strategic are better equipped for performing this developmental role (Atuahene-Gima 1995; Carr and Smeltzer 1999). The above indicates that purchasing has an important role in NPD. In this paper, we make a distinction between (i) purchasing's role in technology selection, (ii) purchasing's role in supplier selection and (iii) its participation on the NPD project. Each of these is discussed in more detail below. 


\subsection{Purchasing's role in technology selection}

One of the main decisions made during the product definition phase is the selection of component technology that will contribute to achieving the level set in the product specifications (Krishnan and Bhattacharya 2002). In the evaluation of potential technologies a set of criteria (Kiani Mavi et al. 2010) can be used to rank the technologies. It is not uncommon that the NPD team is faced with several technological options. In these cases, the NPD team may choose to consider a prospective, yet not fully proven technology that is expected to result in a superior level of performance than that reached by using existing, proven technologies (Krishnan and Bhattacharya 2002). When this technology is developed as part of the NPD project as the prospective technology is not validated, a situation of technology uncertainty arises. Expertise in the the technology may not even reside within the firm, but at external suppliers who are an important source of complementary knowledge (Enkel et al. 2009).

Previous research has provided indications that the role of purchasing is suppressed with increasing technological uncertainty (Oh and Rhee 2010), but has not clearly discussed the role of purchasing in technology selection. Schiele (2010) shows purchasing's role in formulating technology roadmaps with suppliers, an activity not limited to one single NPD project but one that stretches over a longer period of time. These roadmaps can be formulated for a number of technological fields, and reflect technological trends, and evolution of the supply base, and can be directly linked to supplier selection. However, it is not completely clear how purchasing gains access to suppliers' technology roadmaps that are currently not within their industry (Ragatz et al. 2002).

\subsection{Purchasing's role in supplier selection}

When purchasing extends into NPD activities, it has an important role in selecting the suppliers that become involved in the NPD project (McDermott and Handfield 2000; McGinnis and Vallopra 1999; Schiele 2006). Since purchasing is aware of prior collaborations with suppliers, purchasing can contribute not only by assessing new suppliers but also by evaluating prior collaborations. This is important since firms tend to select partners with whom they have a former relationship (Rundquist 2008). Here trust plays a critical role (Kumar et al. 2011). In addition, longer relationships facilitate the building of trust and reduces the risk of opportunism (Burki and Buvik 2010). 
However, in situations of technological uncertainty, the best supplier to select may not be obvious (Eisenhardt and Tabrizi 1995). The initial selection of the supplier becomes an even more critical issue as the buying company needs to anticipate whether the supplier will remain a technology leader (Handfield et al. 1999). Purchasing can contribute with important input to this selection process by having an up-to-date data base of suppliers for different products and technologies (Wynstra et al. 2003). This can be a so-called shortlist of prequalified suppliers, but in situations involving new technology this more likely considers specific considerations regarding the supplier's capabilities, ability to collaborate in NPD, investment possibilities and innovative performance. In fact, the evaluation and selection of suppliers can be based on multidimensional criteria (Oh and Rhee 2010). A recent study showed that for development projects the most important criterion for supplier selection was quality ( $\mathrm{Ng}$ et al. 2012). However, criteria used for supplier selection vary depending on industry (Park et al. 2012).

Oh and Rhee (2010) describe the supplier selection activity as a joint task undertaken by purchasing and R\&D. However, when the selection involved bringing new technologies into the project, it may be that $R \& D$ has the primary responsibility for approaching, evaluating and selecting suppliers (Ragatz et al. 2002). In these cases, and in contrast to more incremental projects, purchasing does not necessarily need to take an active role. In addition, it is not uncommon that technological uncertainty results in firms becoming more inclined to deviate from existing procedures for supplier selection (van Echtelt et al. 2008).

\subsection{Purchasing's participation on the NPD project}

Together with the R\&D department, purchasing is the most relevant internal actor in managing the suppliers that are involved in NPD (Dowlatshahi 1998; van Echtelt et al. 2007). Although there are many studies that present findings on managing supplier involvement in NPD (e.g. Hoegl and Wagner 2005; Lakemond et al. 2006; McIvor and Humphreys 2004; Takeishi 2001; Wagner and Hoegl 2006), fewer studies have a focus on purchasing's activities when managing suppliers in NPD projects. Oh and Rhee (2010) propose the early involvement of purchasing, i.e. after the product planning phase is completed. Knight and Harland (2005) identify six different roles of purchasing: as an innovation facilitator; coordinator; supply policy maker and implementer; advisor; information broker and network structuring agent.

In NPD projects, the role of purchasing focuses on two aspects: the interface with the supplier, and the cross-functional leadership role. The first centres on solving routine 
problems with regard to cost, utility, delivery and payment (Oh and Rhee 2010) throughout the project. Here, purchasing acts as a negotiator, facilitator, supplier's advocate and educator (Wu et al. 2010). Through open communication, the firms can strengthen their relationship and understanding of each other (Smith 2011).

The second aspect is related to keeping the internal organization up-to-date, and takes the view that purchasing takes on a cross-functional leadership role (McGinnis and Vallopra 1999). This can involve sharing important information and intent, as well as involvement in the evaluations of the new technology, discussions about specifications and also early quality assurance (Oh and Rhee 2010). In a cross-functional effort, purchasing, together with R\&D and production, fulfils an important role in the coordination of the development and testing of prototypes (van Echtelt et al. 2008). Moreover, purchasing increasingly needs to integrate with other parts of the business and become team-oriented (Faes et al. 2001).

In situations of technological uncertainty, firms are more likely to share information with their suppliers, especially regarding technology issues (Petersen et al. 2003). In order to facilitate this technology sharing, engineers from the supplying firm may be added to the NPD team (Petersen et al. 2003; Ragatz et al. 2002). The role of purchasing in these situations is not exactly clear. Information sharing with the suppliers increases, but this is mainly between the supplying firm's engineers and the buying firm's engineers. Supplier engineers are added to the NPD team and are even often co-located, which increases the information sharing about the technology. However, it is not certain that purchasing gets a more active role. Indeed, the contrary can also be argued; in such situations it is more likely that the NPD team made up of supplier and buying firm engineers largely "play their own game". Research is lacking in this area however.

\section{Methodology}

This study is based on three case studies of collaborative NPD projects at one firm. The selected firm is a high-tech system integrator with experience in collaborating with external suppliers. Hence, we considered the firm to be appropriate for the purpose of this study. The firm has more than 100,000 employees and a worldwide presence. The case study method was chosen for studying a complex unit with multiple variables (Merriam 1998) in order to gain insight into how purchasing's role can vary between NPD projects at one corporate group. The case sampling strategy was intensity sampling, which consisted of sampling informationrich cases (Patton 2002) to find NPD projects that were suitable for making comparisons. The 
NPD projects were located in the same city and involved technology that was new to the firm and that was provided by external suppliers. All the projects had different suppliers. In the cases, purchasing's involvement in the NPD projects ranged from very little to membership of the NPD team.

The main data consists of interviews, which is a highly efficient method for gathering detailed empirical data (Eisenhardt and Graebner 2007). The respondents sampled consisted of individuals that could influence the NPD projects or who were project members. In this way it was ensured that the respondents had insight into the project and possessed relevant information. To ensure representativeness, individuals with different responsibilities and roles in the project were interviewed. In addition, two of the suppliers were interviewed.

Unfortunately it was not possible to gain access to one of the suppliers. Thus, different views of the projects, processes, meetings and decisions that the firms have made were included. The majority of the respondents were engineers who had management positions within the firms. In addition, the individuals responsible for purchasing in the projects were interviewed. In total, 21 interviews were conducted, four in the first case, seven in the second and 11 in the third. The duration of the interviews ranged from one hour to two hours and thirty minutes. An interview guide that contained open ended questions was used. To reach reliability, we saved our data on a database and used case study protocols (Yin 2009). Additional data consisted of a workshop, internal and external documents, and factory visits.

Following Eisenhardt's (1989) suggestions, the analysis focused on one dimension, in this case purchasing's involvement in the NPD project. Within this dimension, similarities and differences between the three projects were identified. Thereafter, these discoveries were listed in a matrix. To facilitate the comparison, key events in the NPD projects were identified and the process was divided into the different stages of the projects. For instance, the projects were divided into three rough timeframes: technology selection, supplier selection and collaboration with supplier. Finally, to ensure validity, the firms were offered the opportunity to read and comment on the material analysed. The workshop was also an opportunity for us to validate our findings. Ten individuals from the buying firm's R\&D and purchasing department participated. We presented our preliminary results and discussed these with the participants.

\section{Data Presentation}

The research presented in this section is based on three case studies, three NPD projects involving external suppliers that provided technology that was new to the firm. In the case 
firm, purchasing is divided into strategic and operational purchasing. In NPD, strategic purchasing can be involved in the projects. However, the case firm has no policy that prescribes purchasing's strategic involvement in product development. Instead, the firm has guidelines that stress the importance of strategic purchasing's involvement in collaborative NPD where suppliers are included.

The projects studied were conducted at two different entities at the same firm. Project Alpha and Beta belonged to the same unit (power) whereas project Gamma belonged to another entity (motor) at the firm. Collaborative NPD projects have similar structures and processes regardless of their relation to a specific unit. The three projects studied were relatively small; each with fewer than ten members on the project team. Projects Alpha and Beta were NPD projects that involved technology that had not been implemented in similar products previously. In contrast, project Gamma was an NPD project that implemented technology that had been used previously in similar products, but not at the firm in focus. Project Alpha included a smaller supplier that was less powerful, while project Beta and Gamma included large suppliers that were as powerful as the buying firm. An overview of the attributes of the cases is presented in Table 1 .

Table 1 Case overview

\begin{tabular}{llllclc}
\hline Case & Name & Type & Years & \# of project members & Technology & Supplier \\
\hline Case 1 & Alpha & New to industry & 8 & $<10$ & Battery & $\mathrm{A}$ \\
Case 2 & Beta & New to industry & 3 & $<10$ & Battery & B \\
Case 3 & Gamma & New to firm & 1 & $<10$ & Bearing & C \\
\hline
\end{tabular}

\subsection{Project Alpha}

Project Alpha started without any participation from representatives from purchasing. First, the NPD team made an evaluation of the available battery technologies in order to select the most suitable. Technical uncertainties that included future technology development and competing technologies' performance were considered, as well as other factors involving the technical performance of the technology. The technology selected had been developed by supplier A and was the property of that firm. Hence, by selecting the technology, the team had 
also selected supplier A. Therefore there was no evaluation of possible suppliers since there was only one firm that developed the technology selected.

During the project several problems arose. The technical problems consisted of the supplier's limited experience in developing batteries according to the buying firm's requirements. As a solution to the technical problems, the firm invested more resources into helping the supplier with developing and testing batteries. Additional problems were complex and described by the R\&D manager: "We helped them a lot, with many things... which resulted in that we did not have a clear interface between us. This was problematic when we tried to form a commercial agreement" During the project, communication with supplier A was problematic and test results were delayed or not presented, and during the project, supplier A changed strategy and was no longer able to produce a large quantity of batteries once they had been completely developed. The supplier's strategy was now limited to producing prototypes, and they would not be able to manufacture batteries on a large scale. Once these organisational problems emerged, the project came to a standstill and the NPD team could not find a solution to the problem.

The project team contacted purchasing to help solve the organisational problems with the supplier. The purchasing manager described the situation: "The project was technically driven where a number of engineers from both the buying and the supplying firm collaborated [...] neither purchasing nor any other function was involved" Purchasing found that the supplier's processes and routines were insufficient and not suitable for large NPD collaborations. Additionally, supplier A's management demonstrated a lack of interest in the project and could not meet the requirements of the firm. Consequently, it was believed that the supplier had neither the resources nor interest necessary for a development project of this scale. Furthermore, the firm had no plans to build its own manufacturing of batteries, which would have been necessary since the supplier's strategy was restricted to only manufacturing prototypes. As a consequence, it was decided to terminate the collaboration with supplier A.

\subsection{Project Beta}

In this project, the technology was selected by the NPD team, and in contrast to project Alpha, was supplied by a number of firms. However, there was no systematic assessment of the potential suppliers. Instead, purchasing had prior knowledge and positive experience of supplier B and suggested this supplier to the development team. The team had no prior experience of this supplier but agreed that supplier B could be a suitable collaboration partner 
for this project. The selected supplier was a large firm which was used to collaborating in NPD projects with external firms. However, there were some uncertainties in the project. The supplier's project manager explained: “One uncertainty is that we have never made any high voltage batteries. We did not know how the battery electronics would behave in a high voltage environment"

As the project progressed some problematic issues arose related to the supplier. These concerned the rate of activity and commitment to the project from the supplier. The buying firm found that the activity from the supplier was lower than expected and they did not receive the information they requested. However, there was high activity in connection with project meetings between the firms, but after these meetings the activity on the supplier's side decreased once again. At one point, the supplier did not answer any of the buying firm's questions and the firm was told that the supplier did not have enough time for the project. The project team at the buying firm was frustrated and did not know how to deal with the situation. Then, once the collaborative problems arose, purchasing stepped in. The buying firm's project manager remembers: "In the end, the purchasing manager's efforts resulted in a management meeting. [...] We did an analysis of why the situation was as it was. Then the supplier suddenly presented us with a new project manager" The solution from the supplier was to appoint a new project manager and proceed with the project with more enthusiasm.

\subsection{Project Gamma}

In this project, the firm's supply manager was an NPD project member and was thus, a participator throughout the project. However, the technology selection was made without purchasing's involvement. Instead it was the R\&D department that assessed possible technologies and made a selection, in consultation with an external technical expert. The technical uncertainties related to this technology were more limited than in projects Alpha and Beta. This technology is provided by a number of suppliers. In the assessment and selection of suitable suppliers, purchasing as well as representatives from the $R \& D$ department were involved. A number of suppliers were assessed on the basis of their technical skills and firm organisation. It was stressed that not only the technology, but also management and organisational perspectives were important in the supplier selection.

The choice of supplier $\mathrm{C}$ was relatively straightforward. The supplier is well-known in its field, technically very competent and has a proven track record. Furthermore, its organisation is similar to the buying firm's, and it has established routines and processes for conducting 
collaborative NPD projects. Moreover, the firm had used supplier C as a supplier previously, and thus had worked with individuals from supplier $\mathrm{C}$ on earlier occasions. However, at the beginning of the project, the firms had not aligned their goals. The R\&D manager described the situation: "Initially we were far from each other. Supplier C wanted to provide a solution designed for the buying firm. But we were not interested in that. One issue that arose was the cost of the technology supplied, as the costs proved to be much higher than the buying firm had anticipated. The NPD project team had another view of the cost level when they had made the technology selection. Moreover, purchasing had broken down the cost structure of the product and had its ideas what the cost ought to be. The purchasing manager described her role as: "My role in the project was to monitor cost and prices so that we did not only consider what is best from a technological perspective. [...] Much has evolved around getting supplier C to include pros and cons with different ideas from a cost perspective” However, to solve this issue the NPD team, including purchasing, visited the supplier's production plant. At this visit, the firm came to a better understanding of the cost structure. The firm stressed that supplier C's role was not limited to developing a product, but included being a team player and was a part of the firm's competition against other firms. The NPD project was to be viewed as the beginning of a longer collaboration in which the supplier $\mathrm{C}$ was the firm's partner.

\section{Analysis and Discussion}

Due to the absence of a prescribed role for purchasing in NPD, the projects display several differences. Project Alpha did not involve purchasing in the beginning or during the project's progress. It was once problems emerged that purchasing became involved and it was decided that the collaboration with the supplier would be terminated. In contrast, the supplier selection in project Beta was based on purchasing's prior knowledge of the supplier, but was not based on a thorough and systematic assessment. In this project too, purchasing was not involved on a continuous basis. However, once major problems with the supplier emerged, purchasing was contacted to help the project team solve them. For project Gamma, purchasing was included in the supplier selection, and this facilitated the evaluation of potential suppliers. Moreover, in this project, a representative from purchasing was a member of the project team. Hence, the role of purchasing varied in the three NPD projects.

In all three cases, purchasing was not involved in the technology selection at all. R\&D may consider this to be within the domain of its department and not consider involving 
purchasing in such decisions. Previous research has argued that, especially in technologically uncertain projects, the technological selection is an unambiguous decision that can consider suppliers that have previously been considered to be outside the scope of the industry.

Consequently, R\&D does not always considers purchasing to be able to provide relevant input to the technology selection process (Ragatz et al. 2002). This is confirmed in our cases, where purchasing was not involved in technology selection in any of the projects. Even in project Gamma, where the technology was known in the industry, purchasing was not involved. Instead, it was the R\&D department had the responsibility for performing the tasks of finding, assessing and selecting the technology. It must be mentioned that at this stage, interaction with the potential suppliers is rare, and that in our cases, technology selection was largely based on second hand information. So, although technology selection to a large extent limits the choice for suppliers, purchasing's role is negligible. In the projects studied, there was no indication that purchasing formulated technology roadmaps (Schiele 2010), and instead, it was the R\&D department that was responsible for strategic technological decisions in the firm.

An important trigger for involving purchasing is when actual contacts with suppliers need to be established. In our cases, this occurs at the moment of supplier selection. The selection of suppliers is critical to firms as suppliers are increasingly providing input, such as designs for NPD (Kwon et al. 2010). In two of the projects, purchasing played an active role in the selection of suppliers. In the first project, Alpha, purchasing was not involved as the technology selection limited the possible suppliers to only one. Here, due to the technology selection, the firm was locked into one particular supplier (Handfield et al. 1999). Therefore, by selecting the technology the firm automatically selected the supplier as well. As reported in the literature, it is common to include purchasing in the supplier selection for NPD projects (McGinnis and Vallopra 1999; Schiele 2006). This is in accordance with our findings, where purchasing was actively involved in the supplier selection for two of the projects studied. In these projects, the number of potential suppliers was limited and determined by the selected technology, a factor which narrowed purchasing's action space. In the supplier selection, purchasing provided information about the suppliers' products, as shown in other studies (see Wynstra et al. 2003), and also about the suppliers' organisation and NPD procedures. However, purchasing was not the main source of information about the suppliers' technology. Instead, the technologies were investigated by the R\&D department of the firm. In one project, the R\&D department involved an external expert to evaluate the technologies. 
Therefore, this study only partly confirms the suggestion by Wynstra et al. (2003) that purchasing provides information regarding the suppliers' products and technologies. Instead, it seems that R\&D fulfils an equally important role in technologically uncertain projects.

Most surprisingly, the results show a rather low degree of continuous participation from purchasing throughout the NPD project. Only in project, Gamma, which also was the shortest did purchasing become a member of the project team and supported the project throughout. It may be that it is easier to establish commitment to involve purchasing continuously when the NPD project does not span over several years. Our findings support Paulraj and Chen's (2005) study of purchasing, which found a limited use of cross-functional teams. Previous research has argued that, in order for purchasing to be included in the NPD process, it must adapt its organisation to be able to work with long-term technical development. This follows the discussion that purchasing strategies need to be aligned with the firm's strategies, and to have a long-term perspective (Cousins et al. 2006; Narasimhan and Das 2001). In addition, Faes et al. (2001) suggest that purchasing needs to be team-oriented. Our study provides complementary insights with results showing that despite a low degree of continuous participation throughout the NPD project, purchasing may have an important role in assisting R\&D when major problems arise. This study shows that purchasing can assist uncertain NPD projects without being a member of the NPD project team.

So, what is the role of purchasing when suppliers are involved in technologically uncertain NPD projects? Previously, it has been proposed that purchasing has a supporting and facilitating role in the NPD process (Knight and Harland 2005; Schiele 2010). In addition, purchasing's role can also include being active both within the firm and outside the firm as an innovation facilitator (Knight and Harland 2005). Indeed, in the projects studied in this paper, purchasing did support the NPD project by participating in the supplier selection and solving major issues that emerged during the projects. Furthermore, purchasing was active both within and outside the firm. However, purchasing did not respond to daily requests from suppliers as suggested by Knight and Harland (2005), but instead, purchasing responded to problems related to the supplier collaboration. To solve these issues, purchasing acted actively outside as well as within the firm.

Additionally, the literature has identified a role of purchasing as a facilitator (Wu et al. 2010 p. 820) which "portrays the supply manager as being in the middle between the buyer and supplier" and solves problems that occur in the daily operations. Furthermore, the suggested role of purchasing as advisors (Knight and Harland 2005 p. 287) can be viewed as 
them being advisors "called upon to provide formal and informal advice" and in some cases, working as a supply expert. The roles discussed above describe purchasing as facilitating, advising and solving minor problems that occur in daily operations in NPD projects. In projects with technological uncertainty, it seems that the role of purchasing is connected to being a facilitator and supporter.

These roles do not portray purchasing as an external expert, a trouble shooter, solving larger problems. However, this study has shown that purchasing also has a crucial role as a trouble-shooter in uncertain NPD projects, taking a more outside perspective to the on-going supplier relationship which is mainly $R \& D$ driven. This study suggests that a trouble-shooter solves problems in the NPD that have a large impact on the project. In two of the projects described here, purchasing was not involved on a regular basis, but more as an occasional trouble-shooter. Purchasing was contacted when the projects were at a standstill due to major problems related to the supplier. The problem that occurred in project Alpha, which was solved by purchasing, concerned whether or not the firm should continue the collaborative NPD project with the supplier at all. The problem was a conflict with the supplier, where on the one hand the supplier did not manage to develop the requested item and on the other hand, the supplier had changed their business plan from mass-production to a small prototype production. In project Beta, there was a problem due to lack of commitment from the supplier, and here too, purchasing was called in as an external expert to solve the issue. The problem evolved around a lack of communication, low interest and limited input from the supplier. As demonstrated, these problems affected the NPD projects to such a large extent that the projects could not continue before they were solved. This also shows the need for the buying firm to specify each party's responsibilities at every stage of the R\&D project (Wu and Ragatz 2010).

To solve these problems, it was not necessary for purchasing to be present during the entire NPD project. In contrast, purchasing's role as a trouble-shooter could be facilitated by a low degree of continuous involvement in the supplier collaboration. By not being a project member, in project Alpha, purchasing could evaluate the situation without being biased and remain objective in the assessment of the situation and the decisions leading to it. The purchasing manager describes the situation as difficult for the project members: "For the engineers it was painful to terminate the collaboration with the supplier because they had selected the supplier and collaborated with the supplier for a number of years." Similarly, in project Beta, purchasing could enter the project as an outsider, evaluate the situation 
objectively and solve it without having participated in the debate when the problem started escalating. By not being a part of the project, purchasing could be engaged as an external trouble-shooter and be less biased by personal relationships and previous commitments. In fact, purchasing could act as a trouble-shooter and leave the personal relationships between the individuals in the NPD project and at the supplier's largely unaffected.

In the project where purchasing was a member of the NPD project team, purchasing also had a role as trouble-shooter. The problem in this project was related to the cost of the technology, which has been argued to be the responsibility of purchasing (Schiele 2010). Similarly to the other projects, this issue was solved by communicating both inside the firm, with the project team, and outside the firm, with the supplier. In contrast to the other projects, purchasing was not an outsider in this project. Therefore, the role of purchasing as a troubleshooter does not necessarily need to be limited to acting as an outsider. However, it may be that in these situations purchasing is more entangled in the relationship, through personal relationships, previous experiences and commitments.

In this study, the three NPD projects varied in some aspects, which has limited the comparison of the projects. For instance, with regard to time, project Alpha was an eight year project while project Beta was a three-year and project Gamma was a one-year project. On the one hand, a longer collaboration suggests that the relationship between the participants could be stronger. A longer and more expensive NPD project would need a more thorough selection of the supplier. On the other hand, it may be difficult to get a commitment both from R\&D and purchasing to involve purchasing closely in these longer projects. Instead, as long as market release is far away, these projects may be largely R\&D driven. This latter situation seems to apply to our cases.

\section{Conclusions}

At the outset of this paper, we intended to explore the role of purchasing in technology selection, supplier selection, and participation in NPD projects involving suppliers. The study has shown that purchasing has a very limited role in the technology selection for NPD projects, that supplier selection is not always performed systematically, and that purchasing's involvement throughout the NPD project is limited. Not all our findings are in accordance with the literature which usually provides arguments for involving purchasing more deeply, better and more frequently in NPD projects. It might be that our cases are just examples of bad management, but the cases have been conducted at a large and well-performing player in 
the industry, with a long tradition of supplier collaborations. Furthermore, the cases also display important state-of-the-art practice in industry, which in our opinion is not only confined to the specific firm in focus. Consequently, we would like to suggest that our study provides indications that collaboration with suppliers under technological uncertainty is managed differently in NPD projects where suppliers' input mainly consist of manufacturability issues. In these latter projects, purchasing may have a more prominent role than in collaborations under technological uncertainty. To some extent, purchasing may facilitate innovation by supporting $R \& D$, but collaborative innovation is still realized in interaction between $R \& D$ engineers and supplier engineers. Of course, this would be different for standard off-the-shelf supplier products which can be produced without any supplier involvement.

Still, the results of our study show that purchasing has an important role during NPD projects, both in supplier selection and as a trouble-shooter. In supplier selection, purchasing builds on previous experiences with suppliers and/or a thorough assessment of the potential suppliers. When including issues related to the technical capabilities of the supplier, this seems to become a joint effort between R\&D and purchasing. Furthermore, the role of a trouble-shooter refers to purchasing stepping in to solve major problems that have emerged in the NPD project. These can be a lack of commitment and interest from the supplier, conflicts where the supplier has changed its strategy, or conflicts regarding the cost of the technology. To solve these problems, purchasing can but does not necessarily have to be a member of the NPD project.

This study is based on three cases studies and thus generalization is limited. Further research could investigate purchasing's trouble-shooting role further, for instance by focusing on how common this role is in technologically uncertain collaborative projects, systematically investigating the major issues that are resolved by purchasing, and comparing purchasing's role in trouble-shooting as an outsider and insider to the project. Furthermore, we encourage more studies that specifically consider the involvement of suppliers in technological uncertain NPD projects.

\section{Acknowledgements}

The authors wish to thank the reviewers for their helpful and valuable comments on this paper. 


\section{References}

Atuahene-Gima, K. (1995) 'An Exploratory Analysis of the Impact of Market Orientation on New Product Performance', Journal of Product Innovation Management, Vol. 12, No. 4, pp.275-293.

Burki, U., and Buvik, A. (2010) 'Do relationship history and norms matter in overcoming inter-organisational difficulties in the procurement function?', International Journal of Procurement Management, Vol. 3, No. 3, pp.279-291.

Carr, A. S., and Pearson, J. N. (2002) 'The impact of purchasing and supplier involvement on strategic purchasing and its impact on firm's performance', International Journal of Operations \& Production Management, Vol. 22, No. 9, pp.1032-1053.

Carr, A. S., and Smeltzer, L. R. (1999) 'The relationship of strategic purchasing to supply chain management', European Journal of Purchasing \&amp; Supply Management, Vol. 5, No. 1, pp.43-51.

Chen, I. J., Paulraj, A., and Lado, A. A. (2004) 'Strategic purchasing, supply management, and firm performance', Journal of Operations Management, Vol. 22, No. 5, pp.505-523.

Cousins, P. D., Lawson, B., and Squire, B. (2006) 'An empirical taxonomy of purchasing functions', International Journal of Operations \& Production Management, Vol. 26, No. 7, pp.775-794.

Das, A., and Narasimhan, R. (2000) 'Purchasing competence and its relationship with manufacturing performance', Journal of Supply Chain Management, Vol. 36, No. 2, pp.17-28.

Dowlatshahi, S. (1998) 'Implementing early supplier involvement: a conceptual framework', International Journal of Operations \& Production Management, Vol. 18, No. 2, pp.143-167.

Eisenhardt, and Graebner. (2007) 'Theory building from cases: Opportunities and challenges', Academy of management journal, Vol. 50, No. 1, pp.25-32.

Eisenhardt, and Tabrizi. (1995) 'Accelerating Adaptive Processes: Product Innovation in the Global Computer Industry', Administrative Science Quarterly, Vol. 40, No. 1, pp.84-110.

Eisenhardt, K. (1989) 'Building theories from case study research', Academy of management review, Vol. 14, No. 4, pp.532-550.

Enkel, E., Gassmann, O., and Chesbrough, H. (2009) 'Open R\&D and open innovation: exploring the phenomenon', R\&D Management, Vol. 39, No. 4, pp.311-316.

Faes, W., Knight, L., and Matthyssens, P. (2001) 'Buyer profiles: an empirical investigation of changing organizational requirements', European Journal of Purchasing \& Supply Management, Vol. 7, No. 3, pp.197208.

Handfield, R., Ragatz, G., Peterson, K., and Monczka, R. (1999) 'Involving Suppliers in New Product Development?', California Management Review, Vol. 42, No. 1, pp.59-82.

Hoegl, M., and Wagner, S. M. (2005) 'Buyer-supplier collaboration in product development projects', Journal of Management, Vol. 31, No. 4, pp.530-548.

Johnsen, T. E. (2009) 'Supplier involvement in new product development and innovation: Taking stock and looking to the future', Journal of Purchasing and Supply Management, Vol. 15, No. 3, pp.187-197.

Kiani Mavi, R., Makui, A., Fazli, S., and Alinezhad, A. (2010) 'Practical common weights compromise solution approach for technology selection', International Journal of Procurement Management, Vol. 3, No. 2, pp.214-230.

Knight, L., and Harland, C. (2005) 'Managing Supply Networks: Organizational Roles in Network Management', European Management Journal, Vol. 23, No. 3, pp.281-292.

Krishnan, V., and Bhattacharya, S. (2002) 'Technology Selection and Commitment in New Product Development: The Role of Uncertainty and Design Flexibility', Management Science, Vol. 48, No. 3, pp.313327.

Kumar, N., Andersson, D., Isaksson, A., and Olofsson, M. (2011) 'Supplier risk management in direct sourcing from China', International Journal of Procurement Management, Vol. 4, No. 4, pp.363-385.

Kwon, I. W. G., Joo, S. J., and Hong, S. J. (2010) 'Examining the roles of suppliers in large scale system integration using coordination theory: an exploratory study', International Journal of Procurement Management, Vol. 3, No. 4, pp.397-408.

Lakemond, N., Berggren, C., and van Weele, A. (2006) 'Coordinating supplier involvement in product development projects: a differentiated coordination typology', $R \&$ D Management, Vol. 36, No. 1, pp.55-66.

McDermott, C., and Handfield, R. (2000) 'Concurrent development and strategic outsourcing: Do the rules change in breakthrough innovation?', The Journal of High Technology Management Research, Vol. 11, No. 1, pp.35-57.

McGinnis, M., and Vallopra, R. (1999) 'Purchasing and supplier involvement: issues and insights regarding new product success', Journal of Supply Chain Management, Vol. 35, No. 3, pp.4-15.

McIvor, R., and Humphreys, P. (2004) 'Early supplier involvement in the design process: lessons from the electronics industry', Omega-International Journal of Management Science, Vol. 32, No. 3, pp.179-199. 
Merriam, S. B. (1998) 'Qualitative Research and Case Study Applications in Education. Revised and Expanded from "Case Study Research in Education."', San Francisco: Jossey-Bass Publishers.

Narasimhan, R., and Das, A. (2001) 'The impact of purchasing integration and practices on manufacturing performance', Journal of Operations Management, Vol. 19, No. 5, pp.593-609.

Ng, W. K., Zillante, G., Chan, A. P. C., Zuo, J., and Xia, B. (2012) 'Selection of project procurement methods in the consumer electronics industry-a Hong Kong study', International Journal of Procurement Management, Vol. 5, No. 3, pp.289-315.

Oh, J., and Rhee, S. K. (2010) 'Influences of supplier capabilities and collaboration in new car development on competitive advantage of carmakers', Management Decision, Vol. 48, No. 5, pp.756-774.

Park, D., Krishnan, H. A., and Lee, M. (2012) 'A study on global supplier selection decision models', International Journal of Procurement Management, Vol. 5, No. 5, pp.627-646.

Patton, M. Q. (2002) 'Qualitative research and evaluation methods', California: Thousand Oaks, CA: Sage Publications.

Paulraj, A., and Chen, I. J. (2005) 'Strategic supply management: theory and practice', International Journal of Integrated Supply Management, Vol. 1, No. 4, pp.457-477.

Paulraj, A., Chen, I. J., and Flynn, J. (2006) 'Levels of strategic purchasing: Impact on supply integration and performance', Journal of Purchasing \& Supply Management, Vol. 12, No. 3, pp.107-122.

Petersen, K., Handfield, R., and Ragatz, G. (2003) 'A model of supplier integration into new product development', Journal of Product Innovation Management, Vol. 20, No. 4, pp.284-299.

Primo, M. A. M., and Amundson, S. D. (2002) 'An exploratory study of the effects of supplier relationships on new product development outcomes', Journal of Operations Management, Vol. 20, No. 1, pp.33-52.

Ragatz, G. L., Handfield, R. B., and Petersen, K. J. (2002) 'Benefits associated with supplier integration into new product development under conditions of technology uncertainty', Journal of Business Research, Vol. 55, No. 5, pp.389-400.

Rundquist, J. (2008) 'World-class or Good Enough-The Choice of Partner when Outsourcing New Product Development in Medium-Sized Firms', International Journal of Innovation and Technology Management, Vol. 5, No. 4, pp.423-445.

Schiele, H. (2006) 'How to distinguish innovative suppliers? Identifying innovative suppliers as new task for purchasing', Industrial Marketing Management, Vol. 35, No. 8, pp.925-935.

Schiele, H. (2010) 'Early supplier integration: the dual role of purchasing in new product development', $R \& D$ Management, Vol. 40, No. 2, pp.138-153.

Smith, A. D. (2011) 'Successfully managing manufacturing supplier integration and procurement issues: case studies in recessionary environments', International Journal of Procurement Management, Vol. 4, No. 2, pp.121-138.

Song, M., and Di Benedetto, C. (2008) 'Supplier's involvement and success of radical new product development in new ventures', Journal of Operations Management, Vol. 26, No. 1, pp.1-22.

Takeishi, A. (2001) 'Bridging inter- and intra-firm boundaries: Management of supplier involvement in automobile product development', Strategic Management Journal, Vol. 22, No. 5, pp.403-433.

Tomino, T., Park, Y. W., and Hong, P. (2012) 'Strategic procurement through build to order system: an analysis of Japanese auto-manufacturers', International Journal of Procurement Management, Vol. 5, No. 4, pp.413429.

Wagner, S. M., and Hoegl, M. (2006) 'Involving suppliers in product development: Insights from R\&D directors and project managers', Industrial Marketing Management, Vol. 35, No. 8, pp.936-943.

van Echtelt, Wynstra, and Weele, v. (2007) 'Strategic and Operational Management of Supplier Involvement in New Product Development: A Contingency Perspective', Engineering Management, IEEE Transactions on, Vol. 54, No. 4, pp.644-661.

van Echtelt, F. E. A., Wynstra, F., van Weele, A. J., and Duysters, G. (2008) 'Managing supplier involvement in new product development: A multiple-case study', Journal of Product Innovation Management, Vol. 25, No. 2, pp.180-201.

Wasti, S. N., and Liker, J. K. (1997) 'Risky business or competitive power? Supplier involvement in Japanese product design', Journal of Product Innovation Management, Vol. 14, No. 5, pp.337-355.

Wu, S. J., and Ragatz, G. L. (2010) 'Evaluating the total effect of early supplier involvement on project team effectiveness: collaboration and interaction', International Journal of Integrated Supply Management, Vol. 5, No. 3, pp.239-259.

Wu, Z., Steward, M. D., and Hartley, J. L. (2010) 'Wearing many hats: Supply managers' behavioral complexity and its impact on supplier relationships', Journal of Business Research, Vol. 63, No. 8, pp.817-823.

Wynstra, F., Weggeman, M., and van Weele, A. (2003) 'Exploring purchasing integration in product development', Industrial Marketing Management, Vol. 32, No. 1, pp.69-83. 
Wynstra, F., von Corswant, F., and Wetzels, M. (2010) 'In Chains? An Empirical Study of Antecedents of Supplier Product Development Activity in the Automotive Industry', Journal of Product Innovation Management, Vol. 27, No. 5, pp.625-639.

Yin, R. K. (2009) 'Case study research : design and methods', Los Angeles, Calif.: Sage Publications. 